\title{
TOWARDS A CONSISTENCY OF INFORMATION SYSTEMS CURRICULUM
}

\author{
Mehdi Sagheb-Tehrani, Columbus State University,tehrani_mehdi@columbusstate.edu
}

\begin{abstract}
Many MIS/CIS/CS/IT programs are closely following the curriculum guidelines of a widely recognized IS model. However, the decrease in enrollment in Information Systems (IS) programs has motivated many institutions to be innovative in the design of their curricula in order to attract more students to their programs. Therefore it is important to study how to redesign the curriculum for survival in the current economic environment. An understanding of these programs will help us create a more consistent MIS/IS/CIS curriculum that will be challenging and yet attractive to more students. Seventy two (72) IS programs are evaluated in the United States. The main purpose is to compare these programs with 2010-IS model and show the differences that exist between these programs regarding core and elective courses credit hours.
\end{abstract}

Keywords: Management Information System, Computer Information System, Information Technology, Curriculum, Information Systems

\section{INTRODUCTION}

Business managers are very convinced information systems (IS) are changing their business and must ensure that their organization develops and uses information systems to add real value [18]. As the significance of information systems in the business world increases, so does the importance of the quality of our information system college graduates and information systems curriculum. Therefore, the proper education of information systems graduates is becoming more critical. Designing a consistent IS curriculum is a challenging yet necessary process for all educational institutions. Having different curricula offered by various colleges can lead to a chaos in IS education field. Moreover, we have not be able to meet the requirements of our society and our industry in particular. This is the reason that there are different IS models introduced over the past 20 years.

In addition, the technology skills shortage combined with low enrollments in IS related programs indicate a harsh picture for the future of the IT (Information Technology) industry. Many IS programs have experienced enrollment decline of about 70 percent $[15,11]$. Indeed, the cost of paying no attention to this phenomenon is severe. Many CIS/IS/MIS programs have been eliminated or disbanded, and tenured faculty have been laid off [12, 15, and 27]. The perception of an increasing dependency on outsourcing and the "dot com" bust can contribute to declining enrollments. If enrollments continue to decline and if IS-related programs do not deliver graduates with the skills to succeed in the IT industry, the shortage will be worse than originally predicted $[1,26]$. We need to take action to improve enrollment. One main strategy is curriculum redesign.

Designing and redesigning curriculum is a continuous process [10]. There have been many studies and curriculum proposals for IS programs in recent years. The author believes that there are important differences between IS curriculum and IT curriculum. IT curriculum is more technology oriented than IS/CIS/MIS curriculum. One of the best IT curriculum is ACM/IEEE [2]. According to ACM/IEEE-IT [2], an IT academic discipline is defined as following:

As an academic discipline, Information Technology focuses on preparing graduates who are concerned with issues related to advocating for users and meeting their needs within an organizational and societal context through the selection, creation, application, integration and administration of computing technologies.

According to IS-2010 model, an IS academic field defined as following: "Computer-based information systems continue to be a critical part of the products, services, operations, and management of organizations. Indeed, information systems and information technology can be so critical as to disrupt classic business models, threatening traditional revenue streams and even driving industry sectors to extinction. The print newspaper industry, travel agencies, real estate agencies..." As one may notice this definition is not clear compared to IT academic discipline. 
The author believes that IT is the umbrella under which other groups or divisions fall [17]. From a brief examination of IT curricula it appears that IT programs, like IS programs, are very different and typically multi-disciplinary [31, 27]. This study focuses on an IS curriculum model and not the IT curriculum model. In one of the earliest studies, Nunamaker et al. [24] proposed a conceptual model for information systems program. Nunamaker et al. [24] presented the detailed recommendation to Association of Computing Machinery (ACM) curriculum committee.

In a field like IS that is quickly changing, it is important for institutions offering undergraduate programs in IS to periodically evaluate their curriculum and make necessary modifications to meet the demand and requirements of industry [22]. In this study, the IS curriculum of institutions are compared to determine the differences between these curricula. The intention is to study and understand different curricula in IS and determine how a curriculum can be improved. This knowledge of what other institutions are offering should help us redesign our curriculum to stay competitive and attract more students to our IS programs.

\section{RESEARCH METHOD, PROCESS, LIMITATION AND QUESTIONS}

The primary purpose of this study is to design and adopt a MIS/IS/CIS curriculum that meets various skills required by our society. Based upon the literature review and my experience, the type of skills that the industry requires are as following: 1-Programer, Problem solver, Project Manager, Business Analysis, Network and Security Management, and D.B developer (SQL, BI). By doing this we may be able to overcome the low enrollment in this field. This study exerts to put in plain words the concept of MIS/IS/CIS curriculum by reviewing various IS curricula and their relationships with ACM and AACSB. The research introduced draws upon social system theory in the functionalist sociology defined by Burrell and Morgan [6]. This study approaches the subject matter from an objectivist perspective. The proposed model presented is based on the "holistic view" school (Social System Theory). The methodology is based on a literature review, college's web sites and the author's experiences as an IS educator and an IS consultant in numerous universities and organizations.

To obtain a complete list of AACSB schools the author visited The Association to Advance Collegiate Schools of Business website (AACSB). On the website the author was able to view all of the accredited schools in the world. For this research the author focused on those colleges in the United States. A complete lists was generated; then between 1-5 schools from each state were randomly selected, reducing to 104 schools from the original 471 schools for review. By the time of preparing this paper data were collected from 72 universities. The intention was to choose a diverse group of institutions regardless of size and reputation. Next was an online search conducted for institutions with IS programs. Schools were chosen if they had their IS curricular available completely online. The data on total number of credit hours (TCH), IS core course credit hours (ISCCH), business core course credit hours (BCRCH), general education core course credit hours $(\mathrm{GECCH})$, and elective course credit hours $(\mathrm{ECCH})$ were collected and analyzed. From the author's point of view, good research requires a sequence of well-defined steps planned in advance. The following steps were included in this study: Generate research idea, review literature, select schools, review IS curricula, collect data, analyze data and publish the study.

As with any research, this study has limitations. The author believes that there are important differences between IS curriculum and IT (Information Technology) curriculum. IT curriculum is more technology oriented than IS/CIS/MIS curriculum. This study focuses on 2010-IS model (Fig.-1). The data were obtained from 72 different schools. All participating schools in the study were from USA. Another limitation is, this study only considered the schools which were accredited by AACSB. Moreover, there are many other factors that could be part of continued study, such as: considering schools from other accreditation bodies, number of students, internship programs, location of the schools, the name of the programs, job placement and so on. The author faced limitations based upon available resources in order to conduct the study. Further studies might identify additional factors related to the development of CIS curricula. This study as a whole attempts to answer the following research questions (RQ):

RQ: Is there consistency in Information Systems programs offered by AACSB accredited institutions.

H1: There is no consistency in ISC credit hours of IS programs offered by AACSB accredited institutions.

H2: There is no consistency in Elective course credit hours of IS programs offered by AACSB accredited institutions. 


\section{LITERATURE REVIEW}

Many researchers have studied undergraduate IS curricula over the years. For example, [7, 9, 14, 16, 19, 20,21 and 27] studied IT curricula. Moreover, much time has been dedicated to developing model curricula for IS programs in business schools, yet there is no consistency in the department that oversees the degree or in the name of the major. Some common major titles are Management Information Systems (MIS), Information Systems (IS), Computer Information Systems (CIS), and Business Information Systems (BIS) [28]. Educators in this field want to make sure that all the programs continue to meet the requirements of their stakeholders [25]. Curriculum degree programs guidelines for undergraduates in Information Systems (IS) known as an IS model have been developed by the Association for Computing Machinery (ACM) and the Association for Information Systems (AIS). The IS model is widely endorsed and accepted by many institutions. However, there may be noticeable differences between the IS curriculum at various institutions including those who are accredited by different accreditation bodies such as [3, 4]. The main purpose of this research is to examine the IS programs at different institutions to determine how closely they are following the guidelines of the IS model.

The Association for Computing Machinery (ACM) and Association for Information Systems (AIS) has proposed a model curriculum and guidelines for undergraduate degree programs in information systems [29].

\section{Core Courses or IS Courses}

IS 2009.1 Fundamentals of Information Systems

IS 2009.2 Data and Information Management

IS 2009.3 Enterprise Architecture

IS 2009.4 IS Project Management

IS 2009.5 IT Infrastructure

IS 2009.6 Systems Analysis and Design

IS 2009.7 IS Strategy, Management and Acquisition

\section{Elective Courses}

Application Development

Business Process Management

Enterprise Systems

Fundamentals of Human-Computer Interaction

IT Audit and Controls

IT Innovation

IT Security and Risk Management

Figure 1. IS model [29]

This model is focused only on IS education requirements. The core-also known as Information Systems Education Requirement (ISER) and Elective Course (EC) specifications of the latest model IS 2010 are provided below.

\section{Core Courses or IS Courses}

IS 2010.1 Fundamentals of Information Systems

IS 2010.2 Data and Information Management

IS 2010.3 Enterprise Architecture

IS 2010.4 IS Project Management

IS 2010.5 IT Infrastructure

IS 2010.6 Systems Analysis and Design

IS 2010.7 IS Strategy, Management and Acquisition

\section{Elective Courses}

Application Development

Business Process Management

Enterprise Systems 
Human-Computer Interaction

IT Audit and Controls

Data mining / Business Intelligence

Collaborative Computing

Information Search \& Retrieval

Knowledge management

Social Informatics

IT Security and Risk Management

Figure 2. IS model [30]

Association for Computing Machinery (ACM), Association for Information Systems (AIS), and Association of Information Technology Professionals (AITP) have all proposed a model curriculum and guidelines for undergraduate degree programs in information systems [8,13]. The main distinction is the total number of credits offered by the models. The 2002 model is focused more on IS education requirements [26]. The 2002 model offers eleven core courses while the 2009 model offers fourteen courses and 2010 model offers seventeen courses. The 2009 model has made a distinction between the "Core" courses" and "Elective" courses (Fig.1) as well as 2010 model (Fig.2). The 2010 model is almost similar to 2009 model. The only difference is the number of elective courses. The elective courses have increased from 7 courses to 11 courses in 2010 model. Both 2009 and 2010 models have less emphasis on programming courses [5,27]. Some believe that this could help increase the enrollment in IS as many students are driven away from IS programs because of programming requirements. But, the job market requires the programing skills.

It is common for institutions to have different names for their computing programs such as Information Systems (IS), Computer Information Systems (CIS), Information Technology Management (ITM), Business Information Systems (BIS), and Management Information Systems (MIS). In addition, some of the IS programs are Bachelor of Business Administration (BBA) and some are Bachelor of Science (BS). BBA programs emphasize more business courses while BS programs emphasize technology and programming. The primary objective of the IS program is to provide graduates with knowledge, abilities, and attitudes to function effectively as an applications designer/project manager/ programmer /analyst, with the educational background and desire to pursue lifelong professional development. The IS program is very versatile because of the business requirements.

\section{ANALYSIS AND T-TESTING}

The IS programs at the 72 institutions all located in USA were examined and analyzed. A summary of findings is shown in Table-1 and details of each program by institution are provided below. The factors evaluated include the general trend of total credit hours offered by different institutions, Business Education Requirements, Information Systems Education Requirements, General Education Requirements, and Elective Requirements.

In Table-1.2, column two provides the name of institution. Column three (STNA) shows name of state in USA. Column four $(\mathrm{TCH})$ shows the total credit hours required from each university in order to graduate from the program. Last column shows the accreditation of the program by AACSB. In Table-1.2, column one provides the name of institution, column two (TCH) as in Table-1.2 column three (BCRCH) represents the total credit hours requirement for business courses. Column four (\%) shows the percentage of business courses requirement credit hours. Column five (ISCCH) gives the total credit hours requirement for IS courses. Column six (\%) represents the percentage of ISC requirement credit hours. Column seven (GECCH) provides the total credit hours requirement for general education core. Column eight (\%) represents the percentage of general education requirement credit hours. Column nine $(\mathrm{ECCH})$ shows the total elective requirement credit hours. Column ten (\%) provides the percentage of elective requirement credit hours.

Table 2 provides descriptive statistics on the total credit hours, core courses, and elective courses of all the institutions examined in this study along with the core and elective courses of institutions with AACSB accreditation. 


\section{Testing H1 (two tail test)}

Just to restate our hypothesis-1 (H1) of the study "There is no consistency in ISC credit hours of IS programs offered by AACSB accredited institutions". Using the following formula:

$$
t=\frac{\bar{x}-\mu}{\frac{s}{\sqrt{n}}} \quad-1.99 \leq \frac{\bar{x}-\mu}{s / \sqrt{n}} \leq+1.99
$$

One gains $t=5.23$ after inserting all the values $(\overline{\mathrm{x}}=29, \mu=21, \mathrm{~S}=13, \alpha=0.05, \mathrm{n}=72$ and $\mathrm{t}$ value is 1.994$)$ in the above mentioned formula. As the value of $\mathrm{t}=5.23$ lies in the region to right 1.99 , then $\mathrm{H} 0$ is rejected at the 0.05 significant level in favor of H1, i.e., the data support H1. So, one can conclude that there is a significant difference in the Information Systems Courses Requirements (ISC) program in those listed universities.

\section{Testing H2}

Just to restate our hypothesis-2 (H2) of the study "There is no consistency in Elective courses credit hours of IS programs offered by AACSB accredited institutions". One gains $t=-8.40$ after inserting all the values $(\overline{\mathrm{x}}=11, \mu=$ $33, \mathrm{~S}=10, \alpha=0.05, \mathrm{n}=72$ and $\mathrm{t}$ value is -1.994$)$ in the above mentioned formula. As the value of $\mathrm{t}=-18.64$ lies in the region to left 1.99, then $\mathrm{H} 0$ is rejected at the 0.05 significant level in favor of $\mathrm{H} 2$ i.e., the data support $\mathrm{H} 2$. So, one can conclude that there is no consistency in elective courses credit hours of IS programs offered by AACSB accredited institutions.

Therefore the research questions of this study are answered that there is a lack of consistency in core and elective courses credit hours among the accredited institutions of higher education offering the IS program.

\section{CONCLUSIONS}

The Information Systems (IS) discipline faces greater challenges now than at any time; the main challenge is low enrollment (Sagheb-Tehrani 2011). The college curriculum in Information Systems (IS) is revisited and often changed in institutions of higher education to reflect the changes in the field. It is important to make necessary changes to the IS curriculum to make programs challenging and to better prepare graduates for today's job market. Examining the seventy two institutions' IS curricula shows differences in each program (Tables 1.1, 1.2). It is also shown statistically that these programs differ based on core and elective courses credit hours offered regardless of AACSB accreditation. A curriculum is suggested in Figure-3 based on studying these seventy two IS programs and 2010-IS model.

This curriculum consists of business classes and computer information system classes. The degree would be a bachelor of business administration in computer information systems or management information systems. The business courses would be Accounting, Corporate Finance, Micro Economics, Macro Economics, Business Law, Principles of Marketing, and Business Communication. Computer information systems classes would be programming language. Database Management, Systems Analysis and Design, Management Information Systems, Project Management, Networks Management, ERP Systems, Information Security \& Risk Management, IT Management \& Strategy. An Implementation / Internship course will complete the required IS courses. The implementation course / internship would be along the lines of a design project where the student uses everything that he/she has learned and put it into one project. This will give the student experience and maybe a job opportunity at the completion of the program. The IS electives will be required to complete the degree. These classes may be an extra programming course, Computer forensics, Advanced DB, Advance networking management or Advance Webpage Development. Thus, about 30 percent of courses should focus on general college core requirements, 23 percent on BBA core requirements, 39 percent on major specific requirements and about 8 percent open electives (See Figure 3).The findings of the study supported Hypothesis-1 (H1). This can help programs to move towards designing a more consistent CIS curriculum. The result of this study is useful for schools in designing or redesigning the IS program. More detailed research would be required to obtain a better understanding of the deviation uncovered in this paper. 
The primary purpose of this study is to show the existence of differences in the IS curricula of different institution of higher education accredited by AACSB. The findings show lack of consistency in core and elective courses credit hours offered by various institutions offering IS degree programs. This inconsistency exists regardless of the claim for following the IS model curriculum and receiving AACSB accreditation. More institutions should be investigated in different regions with additional criteria such as size, differing accreditation bodies, and reputation. To further validate the differences between the IS programs, more IS curricula in other countries should also be examined. Future studies should identify additional factors related to the value of IS curricula. The focus should also be geared toward the AACSB accredited institutions and be compared to non-accredited institutions. Further studies can focus on other factors mentioned above such as size of the schools and location of the schools.

\section{REFERENCES}

1. Aashim, L, Williams, S and Butler, E.S, (2009). "Knowledge And Skill Requirements For It Graduates", Journal of Computer Information Systems, Spring 2009, pp.48-53.

2. ACM/IEEE - IT 2008. (2008). Information technology undergraduate curriculum model. Association for Computing Machinery. Retrieved October 18, 2009 from http://www.acm.org/education/curricula/ACM/IEEE - IT2008\%20Curriculum.pdf

3. AACSB, http://www.aacsb.edu

4. ACBSP, www.acbsp.org

5. Babb J, Longenecker H.E, Baugh J, and Feinstein, D.L. (2013). "Confronting the Issues of Programming In Information Systems Curricula: The Goal is Success", in Proceeding of Information Systems Education Conference (ISECON) 2013, V30, n2572, San Antonio, Texas, USA.

6. Burrell G, Morgan G (1979), "Social Paradigms and Organization Analysis”, Heinemann, U.S.A.

7. Cameron B.H, (2007), "Enterprise Systems Education: New Direction and Challenges for the Future" in Proceeding of Information Systems Education Conference (ISECON) 2007, V24, §3513, Pittsburgh, USA.

8. Clark J.D., Plotnicki W., Collins F., Longenecker B. and Feinstein D (2012) "Computer Information Systems: A Research Plan to Identify Origins and Destination" in Proceeding of Information Systems Education Conference (ISECON) 2012, V29, n1947, New Orleans Louisiana, USA.

9. Davis, G.B, Gorgone, J.T., Couger, D.J., Feinstein, D.L., and H.E., Longenecker, (1997), "Model Curriculum and Guidelines for Undergraduate Degree Programs in Information Systems," A Joint Report from ACM/AIS/AITP Task Force.

10. Drinka, D., \& Yen, M. Y. (2008). Controlling curriculum redesign with a process improvement model. Journal of Information Systems Education, 19(3), 331-342.

11. Gill, G., and A. Bhattacherjee (2009) "Whom Are We Informing? Issues and Recommendations for Mis Research from an Informing Sciences Perspectivell, MIS Quarterly (33)2, pp. 217-235.

12. Glass, R.L. (2007) "Through a Glass, Darkly*: IS: Doom and Gloom Forecasts?" Information Systems Management (24)4, pp. 393-394.

13. Gorgone J.T., Davis , G.B, Valacich, J.S., Topi, H, Feinstein, L.D, \& Longenecker, H.E,(2002), "IS 2002 Model Curriculum And Guidelines For Undergraduate Degree Programs In Information Systems". http://www.acm.org/education/curric_vols/is2002.pdf?searchterm=gorgone+J.T

14. Janicki T.N, Lenox T, Logan R, Woratscheck C, (2007), "Information Systems/Technology Employer Needs Survey: Analysis by Curriculum Topic, "in Proceeding of Information Systems Education Conference (ISECON) 2007, V24, §2312, Pittsburgh, USA.

15. Koch, H, Slyk C.V, Watson, R., Wells, J, and Willson, R, (2010), "Best Practices for Increasing IS Enrollment: A Program Perspective “, CAIS, Vol.,26, Article 22.DD.477-492.

16. Koohang, A \& Riley, L \& Smith, T and Floyd, K. (2010), Design of an Information Technology Undergraduate Program to Produce IT Versatilists, Journal of Information Technology Education, Vol 9, pp.99-114.

17. Lankford, E. M. (2001) “Teaching IT: A Survey of Terminal Degrees, Hiring and Promotion for Information Technology Professor."Information Systems Education (ISECON2001). Cincinnati, OH, November 2001.

18. Laudon C \& Laudon J.P (2014) “ Management Information Systems: Managing the Digital Firms", $13^{\text {th }}$ ed, Pearson, USA. 
19. Longenecker, H.E, and D.L Feinstein, (1991a)“ A Comprehensive Survey of USA and Canadian Undergraduate Programs in Information Systems," Journal of Information System Education, Volume 3, No.1, Spring 1991, pp.8-13.

20. Longenecker, H.E, and D.L Feinstein, (1991b)“ IS90:The DPMA Model Curriculum For Information Systems for 4 Year Undergraduates,” Park Ridge, Illinois, Data Processing Management Association, 1991.

21. Logenecker, H.E, Feinstein, D.L., Couger, D.J., Davis, G.B, and J.T. Gorgone, (1995) “ Information Systems 95: A summary of Collaborative IS Curriculum Specification of the joint DPMA, ACM, AIS Task Force, “ Journal of Information Systems Education, Volume 6, No. 4, 1995, pp.174-187.

22. Morello. D. (2005). The IT Professional Outlook: Where Will We Go From Here? Gartner, Inc.

23. Nunamaker, J.F, (1981) "Educational programs in information systems, "Communications of the ACM, Volume 24, No. 3, March, 1981, pp.124-133.

24. Nunamaker, J.F, Couger, D.J, and G.B. Davis, (1982) "Information systems curriculum recommendations for the 80s: Undergraduate and graduate programs," Communications of ACM, Volume 25, No.11, November, 1982, pp.781-805.

25. Pierson, J.K, Kruck, S, and Teer, F, (2009). "Trends In Names Of Undergraduate Computer-Related Majors In AACSB-Accredited Schools Of Business In The USA”, Journal of Computer Information Systems, Winter 2008-9, pp.26-33.

26. Sagheb-Tehrani, M, (2007) "Computer Information Systems Department: A Proposition Curriculum for CIS", in proceeding of Information Systems Education Conference (ISECON) 2007, V24, §1542, Pittsburgh, USA.

27. Sagheb-Tehrani M, (2011) “Information Systems Curriculum:Some Concerns” In (IJEED) International Journal Of Education Economics And Development, Vol. 2,No.4,Pages 347-362.

28. Shackelford, R., ed. (2006) "Computing Curricula 2005: The Overview Report," ACM SIGCSE Bulletin, (38:1), pp. 456-457.

29. Topi H, Valacich J.S, Kaiser K, Nunamaker J.F, Sipior J. C, Vreede GJ de, Wright R.T, (2009) “ Curriculum Degree Programs Guidelines for Undergraduate in Information Systems : Association for Computing Machinery (ACM) , Association for Information Systems (AIS) “, http://cis.bentley.edu/htopi/IS2009_05192009.pdf

30. Topi, Heikki, Joseph S. Valacich, Ryan T. Wright, Kate Kaiser, J.F. Nunamaker, Jr., Janice C. Sipior, and GJ de Vreede (2010) "Curriculum Degree Programs Guidelines for Undergraduate in Information Systems : Association for Computing Machinery (ACM) , Association for Information Systems (AIS) “, www.acm.org/education/curricula/IS\%202010\%20ACM\%20final.pdf

31. Woratschek, C. R., \& Lenox, T. L. (2009). Defining CS, IS, and IT: Are we there yet? Information SystemsEducation Journal, 7(59), 1-30. 


\section{Appendix}

Table 1.2. IS Undergraduate Curriculum by Various Universities in USA

\begin{tabular}{|c|c|c|c|c|c|c|c|c|c|c|c|c|}
\hline NO & University & $\underline{\text { ST }}$ & $\underline{\mathrm{TCH}}$ & $\underline{\text { BCR }}$ & $\underline{\%}$ & $\underline{\text { ISC }}$ & $\underline{\%}$ & $\underline{\text { GEC }}$ & $\underline{\%}$ & $\underline{\mathrm{EC}}$ & $\underline{\%}$ & AA- \\
\hline & Name & NA & _ & $\mathbf{C H}$ & - & $\mathrm{CH}$ & & $\mathbf{C H}$ & & $\mathrm{CH}$ & & CSB \\
\hline $\mathbf{1}$ & University of South Alabama & $\mathrm{AL}$ & 123 & 46 & $37 \%$ & 15 & $12 \%$ & 53 & $43 \%$ & 9 & $7 \%$ & Yes \\
\hline 2 & Arkansas Tech University & AR & 124 & 40 & $32 \%$ & 41 & $33 \%$ & 37 & $30 \%$ & 6 & $5 \%$ & Yes \\
\hline 3 & Arizona State University & $\mathrm{AZ}$ & 120 & 31 & $26 \%$ & 21 & $18 \%$ & 60 & $50 \%$ & 8 & $7 \%$ & Yes \\
\hline 4 & University of Colorado-Denver & $\mathrm{CO}$ & 120 & 42 & $35 \%$ & 18 & $15 \%$ & 52 & $43 \%$ & 8 & $7 \%$ & Yes \\
\hline 5 & Georgetown University & DIC & 120 & 36 & $30 \%$ & 48 & $40 \%$ & 24 & $20 \%$ & 12 & $10 \%$ & Yes \\
\hline 6 & Florida Atlantic University & FL & 120 & 54 & $45 \%$ & 21 & $18 \%$ & 36 & $30 \%$ & 9 & $8 \%$ & Yes \\
\hline 7 & $\begin{array}{l}\text { Florida International } \\
\text { University }\end{array}$ & FL & 120 & 54 & $45 \%$ & 30 & $25 \%$ & 36 & $30 \%$ & 0 & $0 \%$ & Yes \\
\hline 8 & Emory University & GA & 138 & 30 & $22 \%$ & 33 & $24 \%$ & 64 & $46 \%$ & 11 & $8 \%$ & Yes \\
\hline 9 & Columbus State University & GA & 123 & 36 & $29 \%$ & 21 & $17 \%$ & 57 & $46 \%$ & 9 & $7 \%$ & Yes \\
\hline 10 & Kennesaw State University & GA & 123 & 18 & $15 \%$ & 15 & $12 \%$ & 42 & $34 \%$ & 48 & $39 \%$ & Yes \\
\hline 11 & University of Hawaii at Monoa & $\mathrm{HI}$ & 124 & 24 & $19 \%$ & 21 & $17 \%$ & 54 & $44 \%$ & 25 & $20 \%$ & Yes \\
\hline 12 & Drake University & IA & 124 & 42 & $34 \%$ & 21 & $17 \%$ & 52 & $42 \%$ & 9 & $7 \%$ & Yes \\
\hline 13 & Iowa State University & IA & 122 & 50 & $41 \%$ & 21 & $17 \%$ & 30 & $25 \%$ & 21 & $17 \%$ & Yes \\
\hline 14 & Boise State University & ID & 129 & 36 & $28 \%$ & 37 & $29 \%$ & 35 & $27 \%$ & 21 & $16 \%$ & Yes \\
\hline 15 & Idaho Stae University & ID & 128 & 43 & $34 \%$ & 18 & $14 \%$ & 37 & $29 \%$ & 30 & $23 \%$ & Yes \\
\hline 16 & loyola University Chicago & $\mathrm{IL}$ & 128 & 42 & $33 \%$ & 15 & $12 \%$ & 45 & $35 \%$ & 26 & $20 \%$ & Yes \\
\hline 17 & $\begin{array}{l}\text { University of Illinois at } \\
\text { Springfield }\end{array}$ & $\mathrm{IL}$ & 120 & 21 & $18 \%$ & 30 & $25 \%$ & 42 & $35 \%$ & 27 & $23 \%$ & Yes \\
\hline 18 & Purdue University & IN & 124 & 57 & $46 \%$ & 12 & $10 \%$ & 48 & $39 \%$ & 7 & $6 \%$ & Yes \\
\hline 19 & University of Notre Dame & IN & 126 & 49 & $39 \%$ & 9 & $7 \%$ & 39 & $31 \%$ & 29 & $23 \%$ & Yes \\
\hline 20 & Kansas State University & KS & 126 & 24 & $19 \%$ & 24 & $19 \%$ & 63 & $50 \%$ & 15 & $12 \%$ & Yes \\
\hline 21 & Pittsburg State University & KS & 124 & 36 & $29 \%$ & 27 & $22 \%$ & 58 & $47 \%$ & 3 & $2 \%$ & Yes \\
\hline 22 & Eastern Kentucky University & KY & 128 & 43 & $34 \%$ & 42 & $33 \%$ & 30 & $23 \%$ & 3 & $2 \%$ & Yes \\
\hline 23 & Morehead State University & KY & 128 & 43 & $34 \%$ & 18 & $14 \%$ & 58 & $45 \%$ & 9 & $7 \%$ & Yes \\
\hline 24 & Grambling State University & LA & 125 & 36 & $29 \%$ & 36 & $29 \%$ & 53 & $42 \%$ & 7 & $6 \%$ & Yes \\
\hline 25 & Nicholls State University & LA & 122 & 36 & $30 \%$ & 39 & $32 \%$ & 42 & $34 \%$ & 5 & $4 \%$ & Yes \\
\hline 26 & $\begin{array}{l}\text { Southern University and A\&M } \\
\text { College }\end{array}$ & LA & 142 & 15 & $11 \%$ & 68 & $48 \%$ & 59 & $42 \%$ & 6 & $4 \%$ & Yes \\
\hline 27 & University of Louisville & LA & 124 & 18 & $15 \%$ & 42 & $34 \%$ & 70 & $56 \%$ & 0 & $0 \%$ & Yes \\
\hline 28 & Bentley University & MA & 122 & 24 & $20 \%$ & 24 & $20 \%$ & 46 & $38 \%$ & 28 & $23 \%$ & Yes \\
\hline 29 & Howard University & MA & 123 & 44 & $36 \%$ & 27 & $22 \%$ & 36 & $29 \%$ & 16 & $13 \%$ & Yes \\
\hline 30 & Morgan State University & MD & 127 & 48 & $38 \%$ & 33 & $26 \%$ & 46 & $36 \%$ & 6 & $5 \%$ & Yes \\
\hline 31 & Towson University & MD & 120 & 12 & $10 \%$ & 52 & $43 \%$ & 56 & $47 \%$ & 9 & $8 \%$ & Yes \\
\hline 32 & University of Maine & $\mathrm{ME}$ & 122 & 0 & $0 \%$ & 53 & $43 \%$ & 69 & $57 \%$ & 0 & $0 \%$ & Yes \\
\hline 33 & Central Michigan University & MI & 124 & 45 & $36 \%$ & 33 & $27 \%$ & 42 & $34 \%$ & 4 & $3 \%$ & Yes \\
\hline 34 & Grand Valley State University & MI & 134 & 45 & $34 \%$ & 58 & $43 \%$ & 31 & $23 \%$ & 0 & $0 \%$ & Yes \\
\hline
\end{tabular}




\begin{tabular}{|c|c|c|c|c|c|c|c|c|c|c|c|c|}
\hline 35 & Oakland University & MI & 128 & 38 & $30 \%$ & 27 & $21 \%$ & 41 & $32 \%$ & 28 & $22 \%$ & Yes \\
\hline 36 & $\begin{array}{l}\text { Minnesota State University } \\
\text { Mankato }\end{array}$ & MN & 127 & 31 & $24 \%$ & 36 & $28 \%$ & 44 & $35 \%$ & 16 & $13 \%$ & Yes \\
\hline 37 & $\begin{array}{l}\text { Minnesota State University } \\
\text { Moorhead }\end{array}$ & MN & 115 & 32 & $28 \%$ & 34 & $30 \%$ & 40 & $35 \%$ & 9 & $8 \%$ & Yes \\
\hline 38 & University of Minnesota & MN & 120 & 20 & $17 \%$ & 74 & $62 \%$ & 46 & $38 \%$ & 0 & $0 \%$ & Yes \\
\hline 39 & $\begin{array}{l}\text { University of Minnesota } \\
\text { Duluth }\end{array}$ & $\mathrm{MN}$ & 120 & 18 & $15 \%$ & 21 & $18 \%$ & 40 & $33 \%$ & 0 & $0 \%$ & Yes \\
\hline 40 & University of Missouri & MO & 120 & 48 & $40 \%$ & 36 & $30 \%$ & 60 & $50 \%$ & 0 & $0 \%$ & Yes \\
\hline 41 & Jackson State University & MS & 120 & 48 & $40 \%$ & 36 & $30 \%$ & 36 & $30 \%$ & 0 & $0 \%$ & Yes \\
\hline 42 & Mississippi State University & MS & 124 & 32 & $26 \%$ & 18 & $15 \%$ & 58 & $47 \%$ & 16 & $13 \%$ & Yes \\
\hline 43 & The University of Mississippi & MS & 126 & 12 & $10 \%$ & 24 & $19 \%$ & 60 & $48 \%$ & 3 & $2 \%$ & Yes \\
\hline 44 & The Univerity of Montana & MT & 120 & 51 & $43 \%$ & 24 & $20 \%$ & 60 & $50 \%$ & 39 & $33 \%$ & Yes \\
\hline 45 & East Carolina University & $\mathrm{NC}$ & 120 & 42 & $35 \%$ & 18 & $15 \%$ & 42 & $35 \%$ & 18 & $15 \%$ & Yes \\
\hline 46 & $\begin{array}{l}\text { Midwest: University of North } \\
\text { Dakota }\end{array}$ & ND & 128 & 49 & $38 \%$ & 23 & 0.18 & 42 & $33 \%$ & 14 & $11 \%$ & YES \\
\hline 47 & $\begin{array}{l}\text { University of Nebraska, } \\
\text { Kearney }\end{array}$ & $\mathrm{NE}$ & 125 & 36 & $29 \%$ & 21 & $17 \%$ & 45 & $36 \%$ & 13 & $10 \%$ & Yes \\
\hline 48 & $\begin{array}{l}\text { University of Nebraska, } \\
\text { Omaha }\end{array}$ & $\mathrm{NE}$ & 125 & 30 & $24 \%$ & 47 & $38 \%$ & 48 & $38 \%$ & 0 & $0 \%$ & Yes \\
\hline 49 & University of New Hampshire & $\mathrm{NH}$ & 128 & 32 & $25 \%$ & 16 & $13 \%$ & 80 & $63 \%$ & 0 & $0 \%$ & Yes \\
\hline 50 & Montclair State University & NJ & 123 & 33 & $27 \%$ & 21 & $17 \%$ & 69 & $56 \%$ & 0 & $0 \%$ & Yes \\
\hline 51 & Rider University & $\mathrm{NJ}$ & 120 & 24 & $20 \%$ & 18 & $15 \%$ & 77 & $64 \%$ & 14 & $12 \%$ & Yes \\
\hline 52 & New Mexico State University & NM & 128 & 62 & $48 \%$ & 27 & $21 \%$ & 39 & $30 \%$ & 0 & $0 \%$ & Yes \\
\hline 53 & The University of New Mexico & NM & 128 & 51 & $40 \%$ & 15 & $12 \%$ & 60 & $47 \%$ & 2 & $2 \%$ & Yes \\
\hline 54 & $\begin{array}{l}\text { University of Nevada, Las } \\
\text { Vegas }\end{array}$ & NV & 124 & 44 & $35 \%$ & 27 & $22 \%$ & 47 & $38 \%$ & 6 & $5 \%$ & Yes \\
\hline 55 & University of Nevada, Reno & NV & 128 & 24 & $19 \%$ & 27 & $21 \%$ & 33 & $26 \%$ & 15 & $12 \%$ & Yes \\
\hline 56 & Clarkson University & NY & 120 & 33 & $28 \%$ & 27 & $23 \%$ & 42 & $35 \%$ & 18 & $15 \%$ & Yes \\
\hline 57 & Cornell University & NY & 124 & 18 & $15 \%$ & 30 & $24 \%$ & 62 & $50 \%$ & 6 & $5 \%$ & Yes \\
\hline 58 & New York University & NY & 128 & 48 & $38 \%$ & 12 & $9 \%$ & 68 & $53 \%$ & 0 & $0 \%$ & Yes \\
\hline 59 & Saint Louis University & PA & 120 & 18 & $15 \%$ & 18 & $15 \%$ & 84 & $70 \%$ & 0 & $0 \%$ & Yes \\
\hline 60 & Clemson University & $\mathrm{SC}$ & 122 & 24 & $20 \%$ & 47 & $39 \%$ & 47 & $39 \%$ & 4 & $3 \%$ & Yes \\
\hline 61 & $\begin{array}{l}\text { East Tennessee State } \\
\text { University }\end{array}$ & $\mathrm{TN}$ & 124 & 22 & $18 \%$ & 55 & $44 \%$ & 41 & $33 \%$ & 6 & $5 \%$ & Yes \\
\hline 62 & $\begin{array}{l}\text { Middle Tennessee State } \\
\text { University }\end{array}$ & $\mathrm{TN}$ & 120 & 24 & $20 \%$ & 24 & $20 \%$ & 44 & $37 \%$ & 6 & $5 \%$ & Yes \\
\hline 63 & $\begin{array}{l}\text { University of Houston-Clear } \\
\text { Lake }\end{array}$ & TX & 120 & 48 & $40 \%$ & 24 & $20 \%$ & 42 & $35 \%$ & 6 & $5 \%$ & Yes \\
\hline 64 & Brigham Young University & UT & 123 & 42 & $34 \%$ & 24 & $20 \%$ & 39 & $32 \%$ & 18 & $15 \%$ & Yes \\
\hline 65 & University of Utah & UT & 120 & 45 & $38 \%$ & 30 & $25 \%$ & 27 & $23 \%$ & 18 & $15 \%$ & Yes \\
\hline 66 & James Madison University & VA & 120 & 39 & $33 \%$ & 28 & $23 \%$ & 41 & $34 \%$ & 12 & $10 \%$ & Yes \\
\hline 67 & Norfolk State University & VA & 121 & 51 & $42 \%$ & 21 & $17 \%$ & 40 & $33 \%$ & 9 & $7 \%$ & Yes \\
\hline 68 & University of Vermont & VT & 122 & 36 & $30 \%$ & 24 & $20 \%$ & 36 & $30 \%$ & 26 & $21 \%$ & Yes \\
\hline 69 & Washington State University & WA & 120 & 42 & $35 \%$ & 9 & $8 \%$ & 0 & $0 \%$ & 12 & $10 \%$ & Yes \\
\hline 70 & Marquette University & WI & 128 & 36 & $28 \%$ & 34 & $27 \%$ & 52 & $41 \%$ & 6 & $5 \%$ & Yes \\
\hline
\end{tabular}




\begin{tabular}{|l|l|l|l|l|l|l|l|l|l|l|l|l|l|}
$\mathbf{7 1}$ & $\begin{array}{l}\text { University of Wisconsin-Eau } \\
\text { Claire }\end{array}$ & WI & 120 & 60 & $50 \%$ & 54 & $45 \%$ & 8 & $7 \%$ & 6 & $5 \%$ & Yes \\
\hline $\mathbf{7 2}$ & $\begin{array}{l}\text { University of Wisconsin-La } \\
\text { Crosse }\end{array}$ & WI & 120 & 28 & $23 \%$ & 36 & $30 \%$ & 56 & $47 \%$ & 0 & $0 \%$ & Yes \\
\hline $\mathbf{7 3}$ & ACM-AIS & & 54 & NA & NA & 21 & $39 \%$ & NA & NA & 33 & $61 \%$ & NA \\
\hline
\end{tabular}

Table 2. Descriptive Statistics for Credit Hours $(\mathrm{CH})$

\begin{tabular}{|l|r|l|r|l|r|l|r|l|r|}
\hline Function & TCH & Function & BCR & Function & ISC & Function & GEC & Function & EC \\
\hline & & & & & & & & & \\
\hline Mean & 124 & Mean & 36 & Mean & 29 & Mean & 47 & Mean & 11 \\
\hline Median & 123 & Median & 36 & Median & 27 & Median & 45 & Median & 9 \\
\hline Mode & 120 & Mode & 36 & Mode & 21 & Mode & 42 & Mode & 0 \\
\hline $\begin{array}{l}\text { Standard } \\
\text { Deviation }\end{array}$ & 4 & $\begin{array}{l}\text { Standard } \\
\text { Deviation }\end{array}$ & 13 & $\begin{array}{l}\text { Standard } \\
\text { Deviation }\end{array}$ & 13 & $\begin{array}{l}\text { Standard } \\
\text { Deviation }\end{array}$ & 15 & $\begin{array}{l}\text { Standard } \\
\text { Deviation }\end{array}$ & 10 \\
\hline Range & 27 & Range & 62 & Range & 65 & Range & 84 & Range & 48 \\
\hline Minimum & 115 & Minimum & 0 & Minimum & 9 & Minimum & 0 & Minimum & 0 \\
\hline Maximum & 142 & Maximum & 62 & Maximum & 74 & Maximum & 84 & Maximum & 48 \\
\hline
\end{tabular}

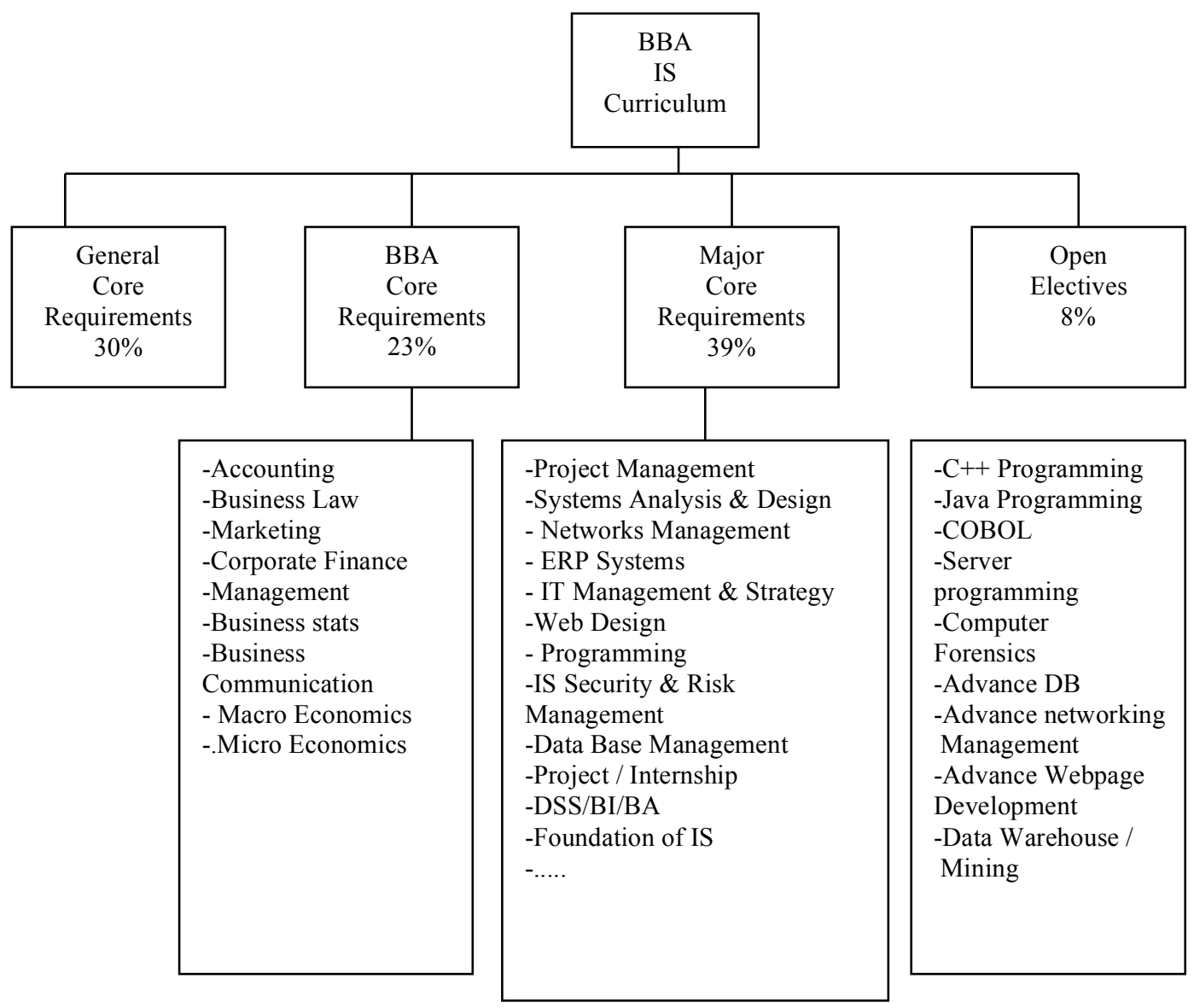

Figure 3. Proposed IS Curriculum 